\title{
Menggagas Pembangunan Blue Economy Terumbu Karang; Sebuah Pendekatan Sosial Ekonomi
}

\section{Ecces: \\ Economics Social and Development Studies}

\author{
Lisa Nursita \\ Fakultas Tarbiyah dan Keguruan \\ UIN Alauddin Makassar
}

Jl. H.M Yasin Limpo No 36, Romangpolong-Gowa, Sulawesi Selatan

E-mail : lisa.nursita@uin-alauddin.ac.id

(Article history) Received: 2020-05-09, Revised: 2020-05-19, Accepted: 2020-06-09, Available online: 2020-06-20 DOI: 10.24252/ecc.v7i1.13730

\section{Abstrak: Menggagas Pembangunan Blue Economy Terumbu Karang; Sebuah Pendekatan Sosial Ekonomi}

Terumbu karang di Pulau Karampuang merupakan aset yang berperan dalam menopang ekonomi masyarakat sekitar. Pengalaman masyarakat setempat mengenai pemanfaatan ekosistem terumbu karang, baik secara sosial maupun ekonomi tidak hanya dapat dinilai secara moneter, tetapi juga dapat dinilai lebih dalam secara kualitatif. Pengkajian dari sisi kualitatif ini, dapat melengkapi penilaian peran penting terumbu karang bagi kehidupan masyarakat sehari-hari. Penelitian ini bertujuan untuk mengetahui manfaat dari ekosistem terumbu karang bagi masyarakat Desa Karampuang Mamuju, baik dari segi sosial maupun dari segi ekonomi. Dari sini kemudian akan diketahui bagaimana sikap masyarakat dalam penggunaan ekosistem ini dan dampak kerusakan ekosistem ini bagi masyarakat, lebih jauh penelitian ini akan bermuara pada simpulan saran kebijakan pengelolaan ekosistem terumbu karang. Penelitian ini dilaksanakan di Pulau Karampuang, Kabupaten Mamuju. Metode penelitian yang digunakan adalah deskriptif kualitatif. Data penelitian ini dikumpulkan melalui survei dan wawancara pada stakeholder yang memiliki hubungan timbal balik dengan terumbu karang di perairan Pulau Karampuang, dengan jumlah informan yaitu sebanyak empat partisipan masing-masing merupakan informan kunci dengan berbagai profesi yang berbeda. Hasil penelitian menunjukkan bahwa pemanfaatan terumbu karang oleh masyarakat setempat bergantung pada terumbu karang tempat mencari nafkah, aset wisata, penjaga pulau dari terjangan gelombang, bahkan bahan bangunan. Melalui penelitian ini dapat dirumuskan beberapa saran alternatif yang efektif mengatasi permasalahan tentang terumbu karang yang ada di 
Pulau Karampuang, diantaranya penerapan payung hukum yang jelas, perencanaan pengelolaan sumber daya terumbu karang yang berkelanjutan berpola blue economy, dan diversifikasi pekerjaan pada masyarakat Pulau Karampuang demi meminimalisir jumlah tekanan pada terumbu karang.

Kata kunci : Ekonomi Biru; Sosial-ekonomi; Terumbu Karang

\section{Abstract: Initiating Development Blue Economy of Coral Reef; An Approach Social Economy}

Coral reefs on Karampuang Island are assets that play a role in sustaining the economy of the surrounding community. The experience of local communities regarding the use of coral reef ecosystems, both socially and economically can not only be assessed in monetary terms but also can be assessed more qualitatively. This qualitative assessment can complement the assessment of the importance of coral reefs in people's daily lives. This study aims to determine the benefits of the coral reef ecosystem for the people of Karampuang Mamuju Village, both in social and economic terms. From this, the attitude of the community in the use of this ecosystem will be known, as well how it will impact them if the ecosystem is damaged. Furthermore, this research will lead to the conclusion of policy recommendations for coral reef ecosystem management. This research was carried out on Karampuang Island, Mamuju Regency. The research method used is the qualitative descritptive analysis. This research data was collected through surveys and interviews with stakeholder who have a reciprocal relationship with coral reefs in the Karampuang Island. This study has 4 informants as a key informant with a variety of different professions. The results showed that the use of coral reefs by society depended on coral reefs for part of their livelihood, tourism assets, coastal protection, and building materials. Through this research, alternative suggestions that can be effectively formulated to overcome the problem of coral reefs on Karampuang Island, including the application of law, planning for sustainable management of coral reef resources with blue economy concept, and diversification of work on the people of Karampuang Island in order to minimize the amount of pressure on the coral reefs.

Keywords : Blue Economy; Social-Economic Benefits; Coral Reef

\section{PENDAHULUAN / INTRODUCTION}

Terumbu karang merupakan salah satu dari beberapa ekosistem yang ada di laut, yang kaya akan keanekaragaman hayati dan memiliki manfaat yang besar di sektor perikanan dan di sektor lainnya. Terumbu karang tidak hanya penting untuk masyarakat pesisir yang berdekatan dengan lokasi terumbu karang, yang mana mereka menjadikannya sumber mata pencaharian, tetapi juga untuk masyarakat nasional dan internasional, dimana terumbu karang memberikan kontribusi dalam berbagai cara pada produksi lautan dan memberikan manfaat lain yang signifikan yang berkaitan dengan perannya di bidang pariwisata, rekreasi dan perlindungan pantai, dan sebagai indikator perubahan iklim dan pengolahan limbah (Fabres dalam Ahmed, Chong, dan Cesar 2005). Terumbu karang di 


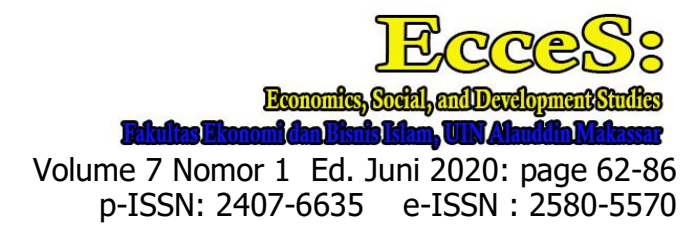

perairan pulau ini memberikan sumbangan besar pada sektor perikanan di Kabupaten Mamuju. Selain memiliki manfaat besar di sektor perikanan, ekosistem terumbu karang di perairan Pulau Karampuang juga memberikan manfaat pariwisata. Ada sekitar 20 ha terumbu karang di perairan Pulau Karampuang yang dijadikan lokasi wisata untuk kegiatan snorkeling dan diving.

Terumbu karang pada dasarnya dapat dimanfaatkan secara berkelanjutan jika tingkat pemanfaatannya tidak melampaui kapasitas produksinya. Wilayah pesisir dan laut memiliki potensi sumberdaya alam yang besar, sehingga dapat dijadikan sumber pendapatan tidak hanya bagi masyarakat pesisir namun juga daerah. Hal ini hanya dapat diselesaikan dengan jalan membangun wilayah pesisir dan laut secara optimal, sehingga pemanfaatan sumberdaya alam yang terkandung didalamnya dapat dilakukan secara berkelanjutan dan sekaligus dapat meningkatkan barang dan jasa, dengan tetap memperhatikan kesejahteraan masyarakat pesisir (Karubaba, Bengen dan Nikijuluw, 2001). Potensi sumberdaya alam wilayah pesisir dan lautan yang sangat besar ini membutuhkan pengelolaan yang baik, sehingga pemanfaatannya dapat berlangsung secara berkesinambungan, sesuai dengan konsep pembangunan berkelanjutan yang menjadi dasar konsep pembangunan nasional. Faktanya dalam pelaksanaan pengelolaan tersebut, faktor keberlanjutan sumberdaya alam sering diabaikan, dengan terjadinya degradasi sumberdaya alam yang memprihatinkan di berbagai daerah, seperti yang terjadi di Pulau Karampuang, sehingga kebijakan baru dan pengawasan ketat dianggap penting diterapkan untuk memperbaikinya.

Upaya pengelolaan pada hakikatnya adalah proses pengontrolan terhadap tindakan manusia agar pemanfaatan sumber daya terumbu karang dapat dilakukan secara bijaksana, dengan mengindahkan kaidah kelestarian lingkungan yang ada (Ikawati et al., 2001). Bagi masyarakat pesisir yang hidupnya mengendalikan hasil laut dan menyatu dengan alam pesisir serta laut sekitarnya, strategi yang digunakan untuk menaikkan pendapatan masyarakat, berbeda dari strategi yang digunakan untuk menaikkan pendapatan masyarakat petani. Masyarakat pesisir pendapatannya sangat bergantung pada kondisi terumbu karang yang ada di perairan laut pesisir. Terumbu karang yang dijamin kondisinya dalam keadaan baik, menjamin kehidupan masyarakat pesisir. Kenyataan menunjukkan bahwa sumber daya alam (SDA) yang ada di sekitar pesisir misalnya terumbu karang semakin rusak kondisinya (Sialagan, 2010). 
Lisa Nursita. Menggagas Pembangunan Blue Economy ...

Pengkajian lebih mendalam tentang pemanfaatan terumbu karang bagi masyarakat sekitar Pulau Karampuang dari sisi kualitatif, dapat melengkapi penilaian peran penting terumbu karang bagi kehidupan masyarakat sehari-hari. Hasil penelitian terkait nilai terumbu karang di perairan Indonesia yaitu Banda Neira, ditemukan bahwa ntotal nilai ekonomi terumbu karang mencapai 17 triliun lebih (Mira, Saptanto dan Hikmah, 2017). Nilai terumbu karang di Pulau Wakatobi mencapai lebih dari empat triliun (Ramadhan, Lindawati dan Kurniasari, 2016). Hal ini membuktikan bahwa terumbu karang memberi sumbangan yang besar, untuk itu menarik dikaji besarnya nilai ini dari sisi kualitatif juga.

Manusia memiliki cara pandang tersendiri dalam memaknai sebuah realitas, sehingga penting adanya pandangan manusia ini dinilai dari segi yang lebih mendalam secara kualitatif. Pengalaman masyarakat setempat mengenai pemanfaatan ekosistem terumbu karang bagi kehidupan mereka baik secara sosial maupun ekonomi tidak hanya dapat dinilai secara moneter tetapi juga lebih dalam yakni secara kualitatif. Dutton et al. (2001) dalam penelitian menyimpulkan kenyataan bahwa pengetahuan formal masyarakat Indonesia tentang sumberdaya pesisir dan laut yang ada kurang. Lebih lanjut dikatakan, hal ini berakibat pada kurangnya dasar pemikiran bagi pengambilan keputusan tentang pemanfaatan langsung sumberdaya pesisir dan laut tersebut.

Tujuan dalam penelitian ini secara umum adalah untuk mengetahui manfaat dari ekosistem terumbu karang bagi masyarakat Desa Karampuang Mamuju, baik dari segi sosial maupun dari segi ekonomi. Dari sini kemudian akan diketahui bagaimana sikap masyarakat dalam penggunaan ekosistem ini dan dampak kerusakan ekosistem ini bagi masyarakat. Penelitian ini akan bermuara pada simpulan saran kebijakan pengelolaan ekosistem terumbu karang. Penelitian ini dilakukan sebagai respon atas isu pemanfaatan yang bersifat destruktif terhadap terumbu karang oleh masyarakat yang ditindaklanjuti dengan usaha-usaha rehabilitasi kondisi terumbu karang. Informasi mengenai persepsi masyarakat tentang terumbu karang di Pulau Karampuang yang minim membuat sulit diambil kebijakan yang efektif untuk menangani pengelolaan yang berkelanjutan terhadap sumber daya pesisir. Untuk itu penting adanya melihat pandangan masyarakat terhadap sumber daya pesisir dan laut sebagai masukan awal dalam program pengelolaan berkelanjutan. Pemanfaatan terumbu karang oleh masyarakat lokal dapat menjadi dasar dalam perencanaan pengelolaan terumbu karang dan sumber daya pesisir lainnya yang tidak merusak ekosistem. Hal ini sesuai dengan yang dikatakan oleh Fox et al. (2001) dalam penelitiannya bahwa tujuan utama dari rencana pengelolaan terumbu karang di Pulau Komodo adalah untuk 


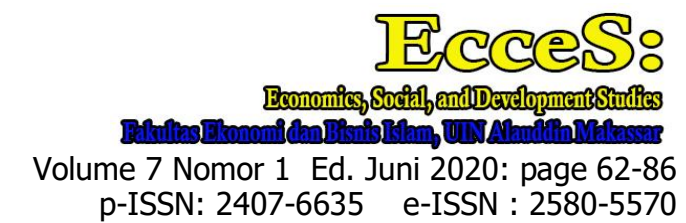

menghentikan permanen kegiatan yang merusak ekosistem laut di lokasi penelitian dan untuk melibatkan masyarakat lokal dalam pengambilan keputusan konservasi, implementasi, dan penegakan hukum. Hasil penelitian ini diharapkan dapat menjadi masukan bagi pengambil keputusan dan masyarakat setempat, serta memberikan gambaran nilai terumbu karang dan manfaatnya bagi masyarakat setempat. Penelitian ini memberikan informasi yang dapat dijadikan bahan pertimbangan dan penentu kebijakan untuk pengambilan keputusan tentang perencanaan pengelolaan sumber daya terumbu karang yang berkelanjutan.

\section{TINJAUAN TEORITIK / LITERATURE REVIEW}

Terumbu karang menyediakan berbagai manfaat langsung maupun tidak langsung. Cesar (2000) menjelaskan bahwa ekosistem terumbu karang banyak menyumbangkan berbagai biota laut seperti ikan karang, mollusca, crustacea bagi masyarakat yang hidup di kawasan pesisir. Selain itu bersama dengan ekosistem pesisir lainnya menyediakan makanan dan merupakan tempat berpijah bagi berbagai jenis biota laut yang mempunyai nilai ekonomis tinggi. Terumbu karang produktivitasnya tinggi. Menurut White dalam Sialagan (2010), terumbu karang mempunyai produktivitas yang sama atau melebihi semua ekosistem alamiah lainnya dan dapat menghidupi rata-rata sekitar 3000 spesies yang hidup di dalamnya.

Menurut Burke, Selig dan Spalding (2002), penurunan kesehatan terumbu dan karang tidak hanya menghilangkan pendapatan dari kegiatan rekreasi dan memancing bagi masyarakat pesisir yang memiliki sedikit atau tidak ada sama sekali mata pencaharian alternatif, tetapi juga telah jauh mencapai konsekuensi nasional dan internasional yang mempengaruhi ekosistem laut yang rapuh dan karunia yang beragam. Menurut Hopley dan Suharsono dalam Burke, Selig dan Spalding (2002) dalam penelitiannya mengungkapkan bahwa manusia amat berperan dalam kegiatan yang merusak terumbu karang. Salah satunya adalah penangkapan ikan yang merusak. Penangkapan ikan menggunakan racun sianida dan bahan peledak telah meluas di Indonesia, bahkan di daerah yang dilindungi. Kerusakan sumber daya pesisir adalah cikal bakal dari minimnya informasi tentang potensi dan peran sumber daya tersebut bagi keberlangsungan hidup masyarakat.

Perhitungan manfaat ekonomi terumbu karang dapat memberikan informasi untuk desain rencana pengelolaan wilayah pesisir. Analisis nilai ekonomi terumbu karang dapat 
Lisa Nursita. Menggagas Pembangunan Blue Economy ...

dilakukan berdasarkan banyak fungsi, yakni: makanan dan sumber daya lainnya (ikan, budidaya laut, perhiasan, item akuarium, dll); bahan konstruksi (pasir, batu); farmasi dan bahan kimia industri lainnya; pariwisata dan rekreasi (diving); pendidikan dan kepentingan ilmiah; dukungan biologi (berkembang biak dan makan ikan lepas pantai); perlindungan kawasan pesisir (untuk mencegah erosi pasir); sumber daya genetik (Bakus, dan Tomascik dalam Seenprachawong, 2001).

Menurut Fabres dalam Ahmed, Chong and Cesar (2005), sama halnya dengan peningkatan manusia, maka terumbu karang pun penting, dengan nilai-nilai sosial dan ekonomi yang beragam dari terumbu karang yang disediakan untuk komunitas yang jauh dan dekat dengan terumbu karang. Nilai-nilai ini termasuk nilai-nilai pasar (terkait dengan produk, fungsi dan jasa), dan nilai-nilai non-pasar (terkait dengan opportunity, budaya, warisan dan existence). Semua nilai-nilai ini dapat dan harus dipertimbangkan dalam hal ekonomi dan digunakan untuk memandu pengelolaan terumbu karang. Terlepas dari kenyataan bahwa keputusan pembangunan dan penggunaan lahan mempengaruhi ekosistem terumbu karang dan kemampuan terumbu karang untuk memberikan jasa dan manfaat bagi kesejahteraan manusia, dalam banyak kasus, keputusan dibuat tanpa mempertimbangkan potensi kerusakan ekosistem terumbu karang. Misalnya, keputusan tentang pembukaan lahan atau penebangan sering tidak memperhatikan sedimentasi, yang merusak ekosistem terumbu karang. Dengan demikian, penting bagi para pengambil keputusan untuk memahami kebutuhan untuk mempertimbangkan nilai-nilai untuk mengidentifikasi dan menilai ketika pembangunan baru direncanakan di pulau-pulau dan di daerah pesisir, dan bagaimana pembangunan ini akan mempengaruhi terumbu karang.

Menurut Dutton et al. (2001), terungkap kurangnya informasi yang dapat diandalkan mengenai persepsi dan sikap masyarakat tentang sumberdaya laut menjadi salah satu masalah dalam program awal Departemen Kelautan dan Perikanan. Kurangnya informasi tersebut tidak hanya mencakup kurangnya pengetahuan tentang bagaimana anggapan berbagai lapisan masyarakat terhadap sumberdaya laut, tetapi juga termasuk tidak adanya konsensus yang valid mengenai aspirasi. Dari konsultasi tersebut, terlihat bahwa pengetahuan akan pandangan masyarakat secara umum terhadap sumberdaya pesisir dan laut serta pemanfaatannya sangat diperlukan sebagai masukan kepada program awal di Departemen Kelautan dan Perikanan yang baru dibentuk.

Howe dalam Suparmoko (2014) menyatakan terumbu karang merupakan sumber daya milik bersama, dalam kaitannya sebagai milik umum adalah adanya pendapat 


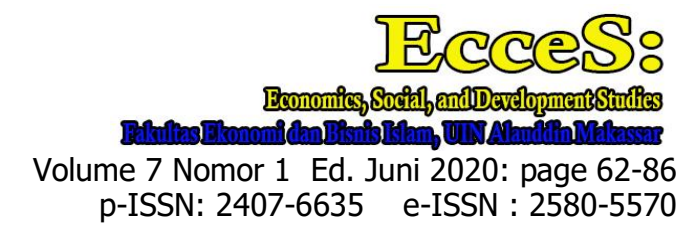

masyarakat yang mengatakan bahwa milik semua orang itu berarti bukan milik siapa-siapa, dan berarti pula milik setiap orang. Melalui pendapat ini, maka akan ada kecenderungan penggunaan sumber daya tersebut secara berlebihan, dan cenderung memberikan tekanan berlibah pada ekosistem yang ada, sampai pada akhirnya muncul deplesi yang berlebihan. Kelompok pesimis yang dipelopori oleh pemikiran Malthus menyebutkan bahwa sumber daya yang terbatas tidak akan mampu mendukung pertumbuhan penduduk yang cenderung tumbuh secara eksponensial, sehingga apabila terus menerus diambil, maka cadangan akan semakin menipis sampai pada saatnya nanti pasti akan habis.

Ricardo dalam Fauzi (2006) menegaskan pandangan itu bertolak belakang dengan kelompok optimisme yang merupakan perspektif Ricardian menyebutkan bahwa sumber daya alam itu tersedia melimpah dan tidak akan pernah habis, termasuk sumber daya alam yang dapat diperbaharui. Ada hubungan yang positif antara jumlah dan kuantitas barang sumber daya dan pertumbuhan ekonomi, tetapi sebaliknya ada hubungan yang negatif antara pertumbuhan ekonomi dan tersedianya sumber daya alam yang ada di dalam bumi (Suparmoko, 2014). Terumbu karang merupakan sumber daya yang tidak dapat diperbaharui, biota laut seperti ikan yang membutuhkan terumbu karang untuk hidup merupakan sumber daya yang dapat diperbaharui namun pada tingkat tertentu bila di eksploitasi melebihi daya pulihnya dapat menyebabkan kepunahan pula.

Smith-Godfrey (2016) mencoba menengahi perdebatan ini bahwa berdasarkan kedua pandangan bertolak belakang antara pemikiran Malthus dan Ricardian, maka butuh inovasi yang bisa dimanfaatkan agar sumber daya kelautan dan perikanan tetap dapat dieksplorasi tanpa menimbulkan deplesi berlebihan, mengingat besarnya peran dan potensi sumber daya terumbu karang bagi keberlangsungan hidup masyarakat pesisir yang sebagian besar masuk kategori miskin. Konsep yang bisa digunakan dalam pengelolaan terumbu karang yang optimal dan dapat meningkatkan kesejahteraan masyarakat adalah blue economy.

Menurut Food Agriculture Organization of United Nations menguraikan blue economy sebagai konsep yang menekankan pada perlindungan dan manajemen yang berkelanjutan, ekosistem laut yang sehat mampu menjadikan laut lebih produktif, dan ini merupakan mutlak harus ada bagi ekonomi yang berbasis kelautan. Smith-Godfrey (2016) mendefinisikan ekonomi biru sebagai "the sustainable industrialisation of the oceans to the benefit of all', dalam jurnalnya, lebih lanjut dikatakan bahwa adanya keseimbangan dalam aktivitas dan nilai. Hal ini berarti bahwa ekonomi biru dianggap sebagai industrialisasi lautan yang memberikan manfaat bagi pengguna/masyarakat dan laut tetap terjaga sehatnya. 
Lisa Nursita. Menggagas Pembangunan Blue Economy ...

Dijelaskan dalam World Wide Fund For Nature (WWF) Baltic Ecoregion Programme, (2015) bahwa salah satu prinsip dalam ekonomi biru adalah definisi yang jelas tentang ekonomi biru yang berkelanjutan. Definisi ini memperjelas bahwa ekonomi biru harus menghormati integritas ekosistem, dan bahwa satu-satunya jalan yang aman menuju kemakmuran jangka panjang adalah melalui pengembangan ekonomi sirkuler. Melalui prinsip ini dapat disimpulkan bahwa ekonomi biru mengedepankan keharmonisan kegiatan ekonomi dan pelestarian lingkungan. Sejalan dengan ini, Hakim (2013) mengatakan bahwa strategi pembangunan perikanan dan kelautan harus terstruktur dan sistematis sehingga tercipta sebuah sinergi antara stakeholder

Sialagan (2010) dalam penelitiannya menyimpulkan bahwa hanya pembangunan yang direncanakan dan dikelola sesuai dengan prinsip pembangunan yang berkelanjutanlah yang menjamin kelestarian sumber daya alam terumbu karang. Lebih lanjut dikatakan bahwa pembangunan yang bertujuan untuk meningkatkan pendapatan masyarakat dapat diselaraskan pembangunannya dengan kelestarian sumber daya alam pesisir, yaitu dengan cara memegang teguh dimensi pembangunan berkelanjutan. Ekonomi biru mampu memberikan solusi dari penggunaan terumbu karang yang berkelanjutan.

Konsep ekonomi biru merubah bagaimana pengelolaan sumber daya alam secara optimal, berkelanjutan dan dengan cara yang bijaksana. Ekonomi biru mencakup pengembangan kawasan, komoditas, inovasi teknologi dan sumber daya manusia serta pengawasan pengelolaan sumber daya alam. Wawasan blue economy dapat menjadi warna kebijakan peraturan daerah, program ekonomi dan pemberdayaan masyarakat (Saefuddin, 2014). Berkaitan dengan ini maka dibutuhkan kerja sama antara pemerintah dan masyarakat dalam mencanangkan perencanaan pengelolaan sumber daya kelautan yang lebih lestari.

Konsep blue economy mengandung unsur keberlanjutan dalam pengelolaan sumber daya alam. Keberlanjutan tersebut terkait pemanfaatan atau proses sumber daya alam secara efektif tanpa limbah, kepedulian sosial, inovasi, dan kreativitas. Untuk mengasah serta mewujudkan hal tersebut adalah melalui ilmu pengetahuan agar memiliki kemampuan dan peranan dalam memanfaatkan sumber daya alam melalui inovasi yang diperoleh dalam dunia pendidikan (Tripon, 2014).

Penerapan konsep blue economy di beberapa daerah di Indonesia telah dilakukan. Adapun penelitian mendukung yang telah berhasil menerapkan konsep ini yaitu Mira, Firdaus dan Reswati (2014) yang menemukan bahwa terdapat tiga usaha perikanan dan 
kelautan pada masyarakat pesisir di Kabupaten Brebes, Jawa Tengah yang telah menerapkan prinsip-prinsip blue economy seperti pada usaha longyam, polikultur, dan usaha pengolahan kulit ikan menjadi kerupuk. Sedangkan daerah yang gagal dalam penerapan konsep ini dikemukakan melalui penelitian yang dilakukan oleh Sukarniati dan Khoirudin (2017) yaitu petani tambak udang di Dusun Ngentak Desa Poncosari Kecamatan Srandakan Kabupaten Bantul belum sepenuhnya mengimplemetasikan konsep blue economy dikarenakan tidak adanya dukungan dari pemerintah dalam usaha ini. Tidak adanya dukungan tersebut berdampak pada kebutuhan sarana yang tidak terpenuhi, sehingga penerapan konsep blue economy tidak dapat diterapkan secara penuh. Selain itu sarana pendukung lain yang diperlukan seperti jalan yang memadai juga tidak tersedia.

Kegagalan dalam penerapannya ekonomi biru bisa saja dikarenakan tidak tepatnya penerapannya yang disesuaikan oleh prinsip tadi yaitu komunikasi tentang konsep ini dengan para pemangku kepentingan, panduan pengambilan keputusan dalam ekonomi biru baik di sektor publik maupun swasta, informasi proses yang menilai kemajuan pengembangan ekonomi biru yang berkelanjutan penilaian, dukungan stakeholder, dan komitmen pemerintah. Untuk bisa menerapkan konsep ini, maka dibutuhkan data informasi tentang bagaimana perkembangan pola pemanfaatan sumber daya yang akan diterapkan konsep blue economy.

\section{METODE PENELITIAN / METHODS}

Metode penelitian yang digunakan adalah pendekatan secara kualitatif dengan menggunakan analisis deskriptif kualitatif. Data yang digunakan dalam penelitian ini adalah data primer yang diperoleh dengan cara wawancara mendalam kepada stakeholder sesuai fokus penelitian, yaitu mengkaji sosial economic benefit dari terumbu karang bagi masyarakat setempat di Pulau Karampuang Kabupaten Mamuju, sikap masyarakat dalam memperlakukan ekosistem ini dan dampak kerusakan ekosistem bagi masyarakat, dari sini kemudian akan ditarik kesimpulan tentang kebijakan yang bisa diambil oleh pemerintah setempat. Data hasil wawancara yang sesuai arah fokus penelitian dikumpulkan, dan data yang tidak relevan, walaupun menarik tidak dimasukkan. Peneliti menentukan dan menemukan partisipan kunci, yang mana partisipan merupakan individu-individu yang menegetahui dengan pasti manfaat terumbu karang bagi masyarakat dan pengguna terumbu karang (Moleong, 1995). 


\section{HASIL DAN PEMBAHASAN / DISCUSSION}

Hasil penelitian ini diperoleh melalui wawancara mendalam dengan partisipan/informan kunci, serta catatan lapangan yang dilakukan pada saat wawancara berlangsung. Terdapat empat klaster tema yang menjelaskan permasalahan penelitian. Klaster tema yang diperoleh yaitu: 1) Peran terumbu karang bagi masyarakat lokal; 2) Kegiatan yang merusak terumbu karang; 3) Penurunan kualitas terumbu karang dan dampaknya bagi masyarakat; 4) Harapan masyarakat pada pemerintah.

Penentuan klaster tema tersebut terbentuk dari proses analisis data yang berasal dari 4 partisipan. Identitas profesi masing-masing partisipan adalah partisipan 1 (P1) adalah nelayan, partisipan 2 (P2) adalah pengumpul (mantan nelayan), partisipan 3 (P3) adalah pengelola pariwisata yang memiliki kerjaan sampingan sebagai nelayan, dan partisipan 4 (P4) adalah kepala desa. Langkah awal proses analisis yaitu ditentukan terlebih dahulu kata kunci setiap partisipan, kemudian ditentukan tema dari setiap partisipan. Beberapa tema level pertama yang memiliki kesamaan arti dianalisis dan digabungkan menjadi tema level kedua. Analisis selanjutnya tema level kedua yang memiliki kesamaan arti digabungkan dalam sebuah klaster tema. Selanjutnya, klaster tema yang telah selesai di coding dan digabungkan tersaji dalam tabel sebagai berikut:

Tabel 1. Daftar Klaster Tema Pemanfaatan Terumbu Karang oleh Masyarakat di Pulau Karampuang

\begin{tabular}{cc}
\hline No & Daftar Tema \\
\hline 1 & Peran terumbu karang bagi masyarakat lokal \\
2 & Kegiatan yang merusak terumbu karang \\
3 & Penurunan kualitas terumbu karang dan dampaknya bagi masyarakat \\
4 & Harapan masyarakat pada pemerintah \\
\hline
\end{tabular}

Sumber: Data Diolah Primer, 2019

Proses analisis data dari setiap klaster tema yang ditemukan, dijelaskan dari uraian setiap tema dengan beberapa kutipan pernyataan partisipan.

\section{Peran Terumbu Karang bagi Masyarakat Lokal}

Beberapa tema muncul terkait manfaat terumbu karang bagi masyarakat lokal yaitu pentingnya keberadaan terumbu karang bagi masyarakat Pulau Karampuang, terumbu karang sebagai penopang hidup nelayan, terumbu karang sebagai rumah ikan, terumbu karang sebagai aset wisata air, dan terumbu karang sebagai penahan ombak.

Masyarakat di Pulau Karampuang sejak kecil telah menjadi nelayan. Pengalaman partisipan terhadap laut dan sumberdayanya sudah bertahun-tahun. Nelayan menjadi 


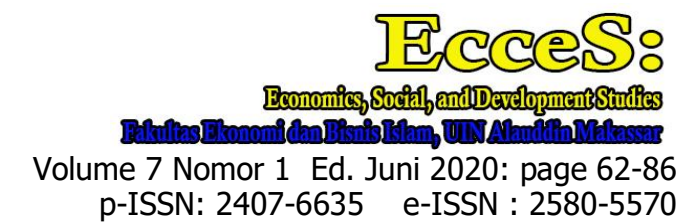

profesi utama para penduduk di Desa Karampuang, walaupun klasifikasi nelayannya mereka bedakan berdasarkan alat tangkap dan jenis biota laut yang ditangkap. Perbedaan klasifikasi ini juga dibedakan berdasarkan lokasi/kluster (bagian utara atau selatan pulau) di Desa tersebut. Tanah yang tandus dan gersang serta berbatu manjadikan pulau tersebut tidak memungkinkan untuk dijadikan lahan bertani, sehingga mutlak mayoritas penduduk menjadi nelayan, sedangkan yang sudah tua dan tidak bisa lagi melaut menjadi pedagang atau buruh kasar. Oleh karena kondisi geografis yang tidak kondusif untuk dialihkan ke sektor lain baik itu pertanian maupun industri, maka semua orang tua menurunkan kemampuan melautnya kepada anak-anaknya yang laki-laki, sedangkan anak perempuan diajari budidaya rumput laut. Hal ini berarti melaut menjadi lahan masyarakat untuk mencari nafkah secara turun-temurun, sehingga kehidupan masyarakat akan sangat bergantung pada laut, untuk itu butuh terumbu karang yang sehat.

"Sudah lama, mungkin sudah 20 tahun"P1

"Saya sudah lama, ... Dulu waktu saya masih bujang, saat telah lulus dari sekolah, saya juga ikut melaut. Jadi saya tahu bagaimana pahit dan manisnya" P2

"Disini semua dari kecil sudah jadi nelayan, jadi sudah lama sekali saya jadi nelayan."P3

"75\% penduduk disini berprofesi sebagai nelayan. Ada yang sebagai nelayan tangkap dengan menggunakan alat pukat, jaring ikan, dan panah. Ada juga yang menjadi nelayan lobster dengan menggunakan jaring... Kalau di Kecamatan Karampuang II banyak yang menjadi pembudidaya rumput laut. Kalau di bagian lokasi wisata, juga ada yang menjadi pembudidaya rumput laut, dan sebagian lainnya menjadi nelayan tangkap menggunakan alat pukat, jaring ikan. Kalau di sini di Kecamatan Karampuang 1 khusus nelayan yang menangkap ikan, teripang, dan kerang japing. "P4

"Iya kami bergantung pada hasil laut, sebab mau berkebun, hanya bisa seperti singkong dan itu pun paling hanya satu tahun sekali baru bisa dipanen. Mau bertani seperti sawah, namun tidak ada sawah di daerah sini. ${ }^{\mathrm{P} 2} 2$

Hasil observasi lapangan menunjukkan bahwa melaut adalah satu-satunya kemampuan yang dimiliki mayoritas masyarakat di Pulau Karampuang, bagi yang tidak bisa melaut, maka mereka memutuskan untuk meninggalkan pulau dan merantau di Ibu Kota Mamuju. Kemampuan melaut tidak hanya dibuktikan dengan sekedar bisa memancing dan mengemudikan kapal, namun juga bisa berenang, menyelam di kedalaman hingga 15-20 meter dengan peralatan seadanya. Sedari kecil anak-anak sudah diajari berenang dan menyelam, bahkan mengendari kapal bermotor. Sekali dua kali dalam observasi, peneliti menjumpai anak kecil mengendarai kapal bermotor seorang diri. 
Lisa Nursita. Menggagas Pembangunan Blue Economy ...

Pernyataan yang memperkuat bahwa dengan melaut nelayan mampu memenuhi kebutuhan hidupnya adalah bahwa dengan melaut nelayan bisa memperoleh penghasilan rata-rata per bulan hingga mencapai Rp 2.000.000,- per orang. Penghasilan ini belum ditambah dengan aktivitas memancing ikan di siang hari dan budidaya rumput lain oleh para ibu rumah tangga. Berkat adanya terumbu karang yang menghasilkan biota laut yang melimpah tersedia di perairan pulau tersebut yang kemudian menjadi sumber pendapatan nelayan membuat kondisi kehidupan nelayan mulai membaik. Hasil tangkapan berupa ikan dan hasil laut lainnya membawa banyak perubahan dlihat dari segi perubahan kondisi kapal nelayan dari yang dulunya tidak bermotor, menjadi bermotor, rumah nelayan yang dulunya rumah panggung atau rumah kayu menjadi rumah batu.

"Jadi begini, dalam ada satu bulan dimana terjadi air laut pasang, yaitu pada saat bulan purnama dan bulan baru. Dan bisa jadi juga terjadi air laut surut, seperti saat sekarang yang terjadi diluar (menunjuk keluar saat dimana saat itu air sedang surut). Jadi biasanya kalau lagi mujur, yah rezekinya banyak, bisa saja kami meraih penghasilan kotor sampai dua juta per orang hanya karena melaut di malam hari. Belum terhitung kerjaan sampingan (seperti mancing ikan, budidaya rumput laut, dII) yang dilakukan pada siang hari. "P2

"Alhamdulillah, teman-teman nelayan ada perkembangan dan kemajuan, dulu orang-orang melaut belum bisa pakai mesin (kapal bermotor), sekarang semua nelayan sudah pakai kapal bermotor. Kemudian dari segi hasil lautnya, karena ada terumbu karang, hasil laut seperti ikan dan semua tangkapan lainnya selama satu tahun jumlahnya lumayan dan harga jualnya juga layak atau sesuai." P2

"Dulu rata-rata penduduk disini memiliki rumah panggung, sekarang sudah berubah menjadi rumah beton. Bisa dilihat dari sebelah sini sampai ke ujung desa sana sudah tidak ada yang menggunakan rumah panggung. 'P2

Peranan terumbu karang dari sebagai rumah ikan sesuai dengan fungsinya yang sebagian diungkapkan oleh masyarakat yaitu sebagai area untuk menghasilkan banyak biota laut, habitat karang, rekreasi, penghalang gelombang, pelindung pantai, bahan/kontruksi bangunan sesuai yang dikatakan oleh Cesar (2000), dan Bengen, Eidman dan Boer (2001). Partisipan mengungkapkan bahwa ekosistem terumbu karang merupakan tempat ikan mencari makan, berkembang biak, mengasuh dan membesarkan anak-anak ikan. Partisipan menggambarkan bahwa terumbu karang merupakan rumah ikan. Terumbu karang di pulau ini juga dijadikan sebagai aset wisata air. Terumbu karang di pulau ini merupakan salah satu asset yang mampu menarik wisatawan. Bagi masyarakat dengan adanya terumbu karang maka setiap hari wisata berlangsung mereka bisa menjual makanan untuk wisatawan dan menyewakan alat snorkeling untuk wisatawan. Dalam seminggu jumlah pengunjung lokal di 
pulau ini bisa mencapai 200 pengunjung, yang tidak hanya terdiri dari wisatawan lokal, tapi juga wisatawan asing. Jumlah ini sangat tergantung oleh cuaca dan besar-kecilnya ombak. Berkat adanya terumbu karang, pemerintah juga mendapatkan pendapatan retribusi setiap tahunnya, dan sebagai langkah meningkatkan jumlah wisatawan, pemerintah melakukan upaya promosi, namun sayangnya belum menunjukkan pengaruh signifikan terhadap jumlah wisatawan yang hadir. Dengan perannya sebagai obyek wisata partisipan menyatakan bahwa terumbu karang di pulau ini harus dilindungi.

"... semua bermanfaat kalau terumbu karang, artinya saling melengkapi, pokoknya ikan dan anak-anak ikan tidak bisa hidup jika tidak ada tempat perlindungannya. Dimana mau bertelur?'P1

"...jadi ini ada dua dek, terus terang terumbu karang dan bakau itu sangat bermanfaat bagi masyarakat kenapa saya katakan seperti itu, karna kita tau terumbu karang dan bakau itu tempat bertelurnya ikan ya, tempat ikan berkembang biak...Juga merupakan salah satu aset yang menarik minat wisatawan"P4

"Sebagai sarana obyek wisata air. Jadi kita harus lindungi terumbu karang ini, karena ini merupakan suatu daya tarik bagi wisatawan yang ingin menikmati pemandangan di bawah air. 'P3

"Tahun 2013 kemarin beramai-ramai banyak datang iorang asing, mereka menyelam... di daerah kesitu (sambil menunjuk ke depan) di daerah utara kesana... Sekitar ada mungkin 20-an, bagi kami 20 orang asing yang datang itu sudah banyak" P4

Ekosistem terumbu karang mengelilingi Pulau Karampuang, dengan begitu terumbu karang menjadi salah satu sumber daya yang dirasakan partisipan ikut menjaga pulau dari terjangan ombak besar. Selain peran terumbu karang yang dapat menahan gelombang penyebab abrasi, batu karang yang mengelilingi pulau juga menjadi penghalau banjir bila musim ombak besar tiba dan bahkan dapat menahan ombak besar sampai ke pelabuhan Kabupaten Mamuju. Artinya peran terumbu karang tidak hanya dirasakan bagi masyarakat Pulau Karampuang tapi juga pulau sekitarnya, sampai ke daerah Kota Mamuju. Berdasarkan hasil observasi, peneliti melihat mulai menemukan dibangun tanggul penahan gelombang dibeberapa tempat tanggul yang dibangun memiliki luas $160 \times 3 \times 1 \mathrm{~m}^{3}$ dan dibangun oleh pemerintah setempat. Hal ini merupakan imbas dari berkurangnya fungsi terumbu karang di beberapa lokasi sebagai penahan gelombang akibat terjadinya kerusakan terumbu karang. Mulai berkurangnya fungsi terumbu karang sebagai penahan gelombang juga mulai dirasakan oleh partisipan dibeberapa bagian pulau. Namun di bagian pulau yang lain yang dikelilingi batu karang membuat tercipta tanggul alami, seperti di daerah wisata yaitu dusun ujung bulo. 
Lisa Nursita. Menggagas Pembangunan Blue Economy ...

"Yang ketiga, tentu dengan adanya terumbu karang itu bisa sedikit mengamankan wilayah ini dari kencangnya ombak"P4

"Seandainya pulau ini tidak ada, maka kemungkinan Kota Mamuju bisa terkena ombak besar pada musim ombak. Dengan adanya pulau ini, maka ombaknya bisa pecah di batu karang di sini (menunjuk ke arah batu). Ooh ombak disini besar, bisa mencapai ketinggian 3 meter. Sedangkan di pelabuhan Kota Mamuju tanggulnya kecil dan tidak bisa menahan ombak besar." $\mathrm{P} 2$

"Nda ada, semua tanggul alam dia pake, semua batu, keliling begini (menunjuk area batu). P2

"Kalau daerah sini nda ada tanggul buatan, semua alami yang digunakan dari batu karang. Artinya abrasinya pantai disinimemang tidak ada, karena sejak dulu pulau ini memang sudah seperti ini, terdiri dari batu-batuan, makanya disebut karampuang, terdiri dari kata karang dan puang. "P4

"Tanggul sudah ada yang dibangun, dikarampuang 1 banyak, ada sekitar 3 hektar. 'P3

\section{Kegiatan yang Merusak Terumbu Karang}

Berdasarkan hasil wawancara dengan 4 partisipan, maka diklasifikasikan beberapa tema terkait kegiatan yang merusak terumbu karang, yaitu tekhnik penangkapan ikan yang salah dan penambangan karang. Aktivitas pengeboman karang merupakan salah satu hal yang menyebabkan terumbu karang rusak dan hilangnya batu karang di Pulau Karampuang. Selain itu, menurut partisipan, kegiatan penembakan ikan salah satu hal yang merusak ekosistem terumbu karang.

"Sebabnya, pernah ada petugas datang sepertinya dari polres akibat adanya aktivitas penangkapan dengan bom dan pembiusan yang menghabiskan karang. Mereka katakan sama saya: 'Pak, didaerah situ antara Pulau Karampuang dan Kota Mamuju (tangan partisipan menggambarkan skema di atas meja), disitu katanya batu karang sudah habis', Saya kemudian mengatakan bahwa : "Apa yang buat jadi seperti itu?' Mereka menjawab 'Bom' 'P2

"Jadi memang alasannya waktu itu rusaknya terumbu karang di Pulau Karampuang itu akibat bom..."P4

"...Kan dulu masih banyak masyarakat yang suka menembak ikan, sekarang sih sudah tidak ada. "P2

Berdasarkan informasi yang diperoleh dari partisipan, separuh dari masyarakat lokal yang berprofesi bukan sebagai nelayan tidak menyadari pentingnya ekosistem terumbu karang bagi kehidupan nelayan. Mereka biasanya mengambil batu karang untuk dijadikan bahan bangunan dan kemudian diperjualbelikan. Partisipan menganggap bahwa jika saja mereka yang menambang karang mau ikut bekerja lebih keras dengan menjadi nelayan, 


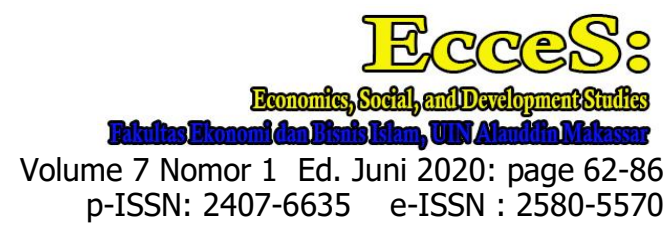

jelas hasil yang mereka dapatkan dari melaut akan lebih besar dibandingkan menjual batu karang. Bertolak belakang dari pernyataan ini, partisipan lain mengungkapkan bahwa penambangan karang dilakukan untuk bangun pondasi rumah warga dan itu pun hanya menggunakan batu kapur atau batu gunung. Dampak dari adanya pariwisata juga membuat timbul sedikit kerusakan yang diakibatkan oleh ulah wisatawan nakal.

"...kadang mereka ini sebagian, tidak sadar tentang pentingnya keberlangsungan terumbu karang, sehingga mereka mengambil batu karang (mengambil batu karang untuk dijual sebagai bahan bangunan)" P1

"Dipinggir bagian sini (menunjuk ke arah pinggir pulau dekat lautan) dulu itu banyak sekali batu-batu besar, kemudian ditambang oleh masyarakat disini dan dijual, banyak batu-batu besar dulu dipinggir-pinggir sini sekarang sudah tidak ada, mereka memperjualbelikannya. Sepertinya harganya 50.000 per kubik"P1

"Kalau prinsip saya begini, mestinya orang-orang berpikir jauh kedepan untuk berusaha melindungi terumbu karang. Mereka penambang tidak memikirkan nasib kami sebagai nelayan. Padahal sebetulnya pendapatan melaut lebih besar dari penambang yang mengambil batu-batu itu. Besar juga pendapatannya daerah dari hasil, dibandingkan bila mereka ambil begitu sama karangnya dan dijual... "P1

"Disini batu pondasi rumah tidak dibeli, pasir juga tidak, tinggal diambil di alam... yang diambil batu laut, kadang juga batu gunung. Warga ambil sendiri. "P2

"Warga kadang biasanya mengambil batu untuk pondasi rumah, ... , kalau penambangan karang disini ga ada, hanya sejenis batu kapur. "P3

"...Kalau wisatawan paling ambilnya bintang laut. "P4

\section{Penurunan Kualitas Terumbu Karang dan Dampaknya bagi Masyarakat}

Terdapat perbedaan persepsi masyarakat mengenai kerusakan lingkungan yang saat ini terjadi disekitar mereka. Partisipan 1 yang merupakan seorang nelayan menganggap karena kerusakan terumbu karang yang terjadi saat ini, maka jumlah hasil tangkapannya berkurang. Lebih lanjut diungkapkan bahwa perubahan yang terjadi pada terumbu karang di perairan Pulau Karampuang sangat besar. Hal ini menimbulkan gelombang air menjadi lebih tinggi dan tingkat kedalaman pada saat air pasang lebih dalam dibanding tingkat kedalamannya dulu. Sedangkan Partisipan 3 dan 4 yang merupakan Kepala Desa dan pengelola wisata menganggap bahwa kondisi terumbu karang di Pulau Karampuang sudah mulai membaik sejak masyarakat setempat dan pemerintah sudah mulai sadar bahwa terumbu karang memiliki banyak manfaat dan keberadaanya penting bagi keberlangsungan hidup nelayan. Berdasarkan hasil observasi, peneliti melihat jarak nelayan melaut memang 
Lisa Nursita. Menggagas Pembangunan Blue Economy ...

cukup jauh dari bibir pantai, dan mulai pula dibangun beberapa tanggul, sehingga dapat disimpulkan dari pengamatan langsung bahwa sudah mulai muncul kerusakan.

"Kerusakan sudah mencapai 75\%. Akibatnya pendapatan berkurang drastis. Mungkin sekitar 2 kali lipat penurunannya dari saat ini. Dulu waktu saya masih kecil, cari ikan cukup dibibir pulau saja, sekarang susah... Dulu, kalau saya turun ke air di pinggir sana, kepala saya masih tidak tertutup air, (partisipan berdiri dan menaruh tangan di dada), tidak tenggelam, kalau sekarang jangan coba-coba."P1

"Semakin lama semakin banyak... Kondisi terumbu karang semakin bagus. Memang awalnya dulu sebelum wisata dikelola, memang banyak rusak, tapi sekarang kita sudah artinya sudah dilindungi, dilarang lagi orang merusak. 'P3 "Kalau menurut saya, kerusakan sekitar 20 \%, 80 \% sisanya masih bagus. "Alhamdulillah kalau terumbu karang dek masih aman, masyarakat juga tidak mengganggu ya habitatnya itu. 'P4

\section{Harapan Masyarakat pada Pemerintah}

Seorang partisipan berharap ada penindakan tegas dari pihak pemerintah terhadap mereka yang melakukan penambangan karang. Partisipan merasa jika tidak ada tindakan tegas dari pihak pemerintah bisa jadi terumbu karang di perairan Pulau Karampuang menjadi habis. Lebih jauh nelayan mengungkapkan keterkaitan mereka yang erat terhadap habitat terumbu karang yang lestari. Nelayan merasa hanya melaut satu-satunya hal yang anak-cucu mereka bisa lakukan, mereka tidak memiliki kemampuan lain kecuali menjadi nelayan, sehingga hanya pada laut mereka menggantungkan masa depan. Selanjutnya, dari sektor pariwisata, butuh peningkatan sarana dan prasarana. Partisipan 3 mengatakan sudah ada langkah untuk meningkatkan sarana dan prasarana dari pemerintah.

"Kalau kerusakan terumbu karang yang terjadi dibiarkan oleh pemerintah, maka bisa jadi akan semakin habislah terumbu karang kami... Cuma ini yang bisa dikerja oleh anak cucu kami, jika tidak ada terumbu karang, laut tidak menghasilkan apa-apa, maka dimanalah mereka bisa mencari uang? Bisa-bisa mereka merampok, tidak ada masa depan. 'P1

"Jadi mudah2an program pariwisata tahun 2015, termasuk pembuatan gazebo dengan polteks, termasuk rehab ini jembatan (dermaga). Baru selesai direhab kaya ini, (menunjuk ke dermaga) datang ombak hancur lagi. 'P3

Berdasarkan hasil penelitian yang telah diuraikan akan dibahas interpretasi hasil penelitian yang dilakukan dengan membandingkan hasil penelitian dari wawancara dan observasi/pengamatan yang dilakukan. Hal ini penting untuk membuktikan bahwa yang diungkapkan partisipan merupakan realitas yang sesungguhnya. 


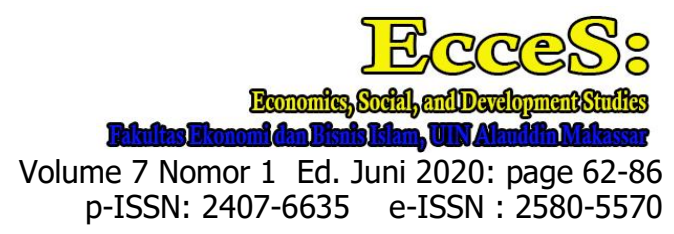

Terumbu karang erat kaitannya dalam keseharian penduduk lokal. Terumbu karang dipandang sangat bermanfaat bagi penduduk setempat. Terumbu karang merupakan ekosistem yang memberikan pendapatan kepada masyarakat setempat utamanya nelayan. Nelayan memanfaatkan terumbu karang sebagai tempat memancing dan mencari ikan. Walaupun di sepanjang pulau juga terdapat mangrove, namun nelayan lebih memilih memancing di sekitar daerah terumbu karang, sedangkan di sekitar mangrove nelayan biasanya memasang perangkap/jaring/pukat. Keberadaan terumbu karang sangat penting bagi keberlangsungan hidup nelayan dan anak-cucunya. Hal ini berarti bahwa keberadaan terumbu karang menjadi tumpuan dalam mencari pendapatan nelayan di sana. Berkat hasil laut yang diperoleh nelayan, hampir seluruh masyarakat setempat dapat memenuhi kebutuhan hidupnya. Menunjang hasil penelitian tersebut, dikatakan oleh Cesar (2000) bahwa ekosistem terumbu karang banyak menyumbangkan berbagai biota laut seperti ikan karang, mollusca, crustacea bagi masyarakat yang hidup di kawasan pesisir. Selain itu bersama dengan ekosistem pesisir lainnya menyediakan makanan dan merupakan tempat berpijah bagi berbagai jenis biota laut yang mempunyai nilai ekonomis tinggi.

Selain dimanfaatkan secara langsung melalui hasil laut, terumbu karang juga dimanfaatkan sebagai input wisata air di Pulau Karampuang. Dalam seminggu daerah wisata terumbu karang dapat menarik wisatawan sebanyak 100 - 200 pengunjung. Kondisi pantai yang surut di pagi dan siang hari hingga hanya memiliki kedalaman sekitar $30-100$ centimeter, banyaknya hewan laut seperti belut, ikan kecil, bulu ayam, serta banyaknya karang di sepanjang pantai, baik itu karang hidup maupun karang mati, menjadikan pantai tidak dapat digunakan untuk berenang. Hal ini berarti bahwa snorkeling dan diving merupakan satu-satunya aktivitas wisata yang bisa dilakukan oleh wisatawan. Jernihnya air di sekitar terumbu karang memungkinkan wisatawan dapat melihat keindahan terumbu karang tanpa harus menyelam namun hanya dengan berdiri di atas dermaga atau perahu. Dengan demikian terumbu karang merupakan input tunggal yang menarik datangnya wisatawan untuk berkunjung. Dengan dibukanya lokasi wisata, maka masyarakat setempat juga mendapatkan keuntungan, yakni mendapatkan tambahan pendapatan. Artinya bahwa terumbu karang di Pulau Karampuang memberikan multiplier effect dari segi wisata kepada penduduk setempat dan menyumbangkan retribusi daerah pada Kabupaten Mamuju setiap tahun. Lebih lanjut disampaikan bahwa objek wisata bahari terumbu karang di Pulau Karampuang dikatakan oleh partisipan yang berprofesi sebagai pengelola wisata mampu memberikan retribusi pada pendapatan daerah Kabupaten Mamuju. Sumbangan objek 
Lisa Nursita. Menggagas Pembangunan Blue Economy ...

wisata terhadap pendapatan daerah sesuai dengan yang disebutkan oleh Nessa, Jompa dan Hasmin (2014) dalam bukunya bahwa beberapa jumlah sumbangan pendapatan dari pariwisata bahari akibat adanya terumbu karang di beberapa daerah di Indonesia, diantaranya di Wakatobi mampu memberi pendapatan sebesar Rp 15 M, di Sulawesi Utara sebesar Rp 22 M setiap tahunnya. Dikatakan bahwa nilai ini sangat berarti dari penting terutama bagi daerah yang tidak memiliki sumber pendapatan lain yang signifikan misalnya di Sulawesi Barat.

Dalam hasil wawancara juga ditemukan bahwa partisipan menganggap terumbu karang sebagai "Penjaga Pulau", bahkan dengan adanya terumbu karang di perairan Pulau Karampuang, maka Kabupaten Mamuju juga ikut terhindar dari terjangan ombak besar. Hal ini berarti terumbu karang berperan sebagai penahan ombak atau penahan gelombang. Sejalan dengan yang dikatakan oleh Fabres dalam Ahmed, Chong dan Cesar (2005) bahwa terumbu karang memberikan kontribusi dalam berbagai cara pada produksi lautan dan memberikan manfaat lain yang signifikan yang berkaitan dengan perannya di bidang pariwisata, rekreasi, perlindungan pantai, dan sebagai indikator perubahan iklim dan pengolahan limbah.

Manfaat tambahan yang dirasakan masyarakat dengan adanya terumbu karang adalah dapat dimanfaatkan sebagai batu pondasi rumah. Hal ini sejalan dengan temuan Sembiring, Wantasen dan Ngangi (2012) di Kabupaten Tumbak Minahasa Utara yaitu sebanyak $70 \%$ respondennya memanfaatkan terumbu karang sebagai pondasi rumah. Berdasarkan hasil observasi peneliti di Pulau Karampuang, pemanfaatan batu karang sebagai pondasi rumah dilakukan untuk meminimalisir biaya pembangunan rumah, untuk itu masyarakat membangun rumah dengan memanfaatkan 'hadiah' yang sudah diberikan oleh alam, mulai dari pasir sampai kepada batu karangnya. Termasuk pekerja yang membangun rumah berasal dari sistem gotong royong yang masih melekat. Sejalan dengan temuan ini Kordi (2010) menguraikan bahwa masyarakat desa sebagian besar menggunakan karang sebagai pondasi rumah karena berbagai alasan dan yang terutama karena meringankan mereka dari segi dana.

Peranan terumbu karang yang begitu besar jelas memberi dampak yang besar pula bila terumbu karang rusak, diantaranya dapat membuat populasi ikan di sekitar pulau menjadi sedikit, artinya pendapatan nelayan pun menjadi berkurang. Hal serupa juga ditemukan oleh Ramadhan, Lindawati dan Kurniasari (2016) di lokasi penelitiannya yaitu Pulau Wakatobi, dimana besarnya nilai ekologi terumbu karang menunjukkan pentingnya 


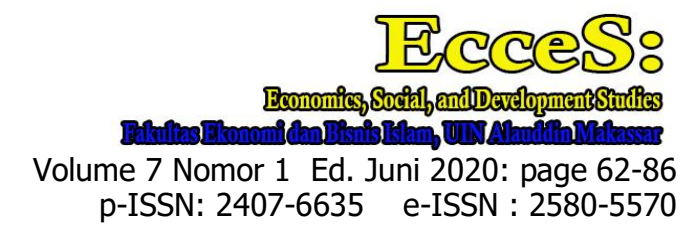

perairan ekosistem ini dimana rusaknya ekosistem berpotensi membebani negara dengan biaya yang sangat besar hanya untuk menjaga keberlanjutan lingkungan ekosistem peisisr di Wakatobi.

Berdasarkan hasil observasi dan wawancara, kegiatan-kegiatan yang merusak ekosistem terumbu karang adalah penambangan karang, teknik penangkapan ikan yang salah, dan pembuangan sampah oleh penduduk di laut. Hal yang menarik muncul pada saat wawancara dimana terdapat perbedaan persepri masyarakat terkait masalah kerusakan lingkungan yang timbul. Mereka yang berinteraksi langsung dan telah merasakan perbedaan hasil tangkapan memberikan persepsi nyata yang mendekati kondisi yang sesungguhnya dimana benar telah terjadi kerusakan dibeberapa tempat, dan nampak juga kerusakan tersebut dari hasil observasi peneliti. Perbedaan persepsi ini merupakan bukti nyata bahwa adanya ketidaktahuan dan ketidakpekaan masyarakat terhadap fenomena yang terjadi disekitarnya. Menurut Dutton et al. (2001), persepsi masyarakat beragam sejalan dengan ragam lokasi dimana mereka tinggal dan terlihat kurangnya pengetahuan dalam hal-hal yang mendasar sekalipun mengenai fenomena yang ada di luar wilayah tinggalnya.

Terkait masalah penambangan karang secara ilegal yang kemudian digunakan sebagai batu pondasi, menunjukkan adanya perubahan fungsi terumbu karang dari yang seharusnya. Oleh karena semakin rendahnya kualitas ekosistem terumbu karang di Pulau Karampuang, sehingga sebagian masyarakat memutuskan untuk menambang liar terumbu karang yang kemudian hasilnya dijual. Hal ini sesuai dengan yang dikatakan oleh Adrianto, (2006) bahwa secara konseptual, apabila ada gangguan terhadap sistem sumber daya alam, maka kemampuan sumber daya alam untuk menghasilkan aliran barang atau jasa menjadi terganggu (infured). Gangguan ini mengakibatkan perubahan produksi barang dan jasa yang pada akhirnya akan mengubah perilaku pemanfaatannya. Perubahan ini akan mengubah nilai dari sumber daya alam tersebut.

Sektor pariwisata juga mempengaruhi terjadinya kerusakan terumbu karang di Pulau Karampuang. Berdasarkan hasil observasi diketahui bahwa ada ulah wisatawan nakal yang membawa pulang terumbu karang dan bintang laut hidup dari lokasi wisata. Tidak adanya pengawasan oleh pengelola wisata membuat wisatawan dapat berbuat sesuka hatinya walaupun tindakan tersebut jelas merusak input wisata yang ada. Hal ini sejalan dengan yang dikatakan oleh Nessa, Jompa dan Hasmin (2014) dalam bukunya yakni penyebab lain yang menimbulkan kerusakan terumbu karang di Indonesia pada beberapa wilayah salah satunya adalah kegiatan rekreasi. 
Lisa Nursita. Menggagas Pembangunan Blue Economy ...

Selain itu, pembuangan jangkar dari perahu motor penghubung lokasi wisata dengan Kota Mamuju di atas terumbu karang juga mengakibatkan terjadinya kerusakan pada terumbu karang, ditambah lagi dengan tindakan nahkoda kapal yang membuang jangkar di atas karang, dan menjadi area terumbu karang sebagai pelabuhan sementara. Aktivitas yang membuat timbulnya kerusakan terumbu karang ini sesuai dengan hasil penelitian Sudirman et al. (2006) di lokasi wisata bahari terumbu karang Kabupaten Bulukumba, yang menemukan bahwa sebesar 25 persen penyebab kerusakan kerusakan terumbu karang di Kabupaten Bulukumba Sulawesi Selatan disebabkan oleh jangkar perahu, dimana lokasi ini merupakan penambatan perahu nelayan dan dijadikannya kawasan ini sebagai pelabuhan alami.

Penggunaan alat tangkap ikan yang tidak ramah lingkungan juga ikut mempengaruhi kerusakan lingkungan yang terjadi pada terumbu karang di Pulau Karampuang. Berdasarkan hasil wawancara dan observasi diketahui masih ada nelayan yang menggunakan alat panah untuk menangkap ikan, dan ini rentan mengenai terumbu karang. Pengaruh alat tangkap ikan terhadap kerusakan terumbu karang juga tergambar dalam hasil penelitian yang dilakukan oleh Cinner et al. (2013) yang menyimpulkan bahwa peninjauan alat tangkap ikan atau peralatan memancing karena rawan mengakibatkan pemutihan karang. Kerusakankerusakan yang terjadi menurunkan jumlah hasil tangkapan nelayan dari tahun ke tahun. Partisipan yang juga berprofesi sebagai nelayan yang setiap harinya memancing ikan dan menyelam di sekitar wilayah terumbu karang mengatakan bahwa kerusakan terumbu karang mencapai $75 \%$, yang berdampak pada menurunnya jumlah ikan tangkapan akibat kerusakan yang terjadi di terumbu karang. Di sisi lain, partisipan lainnya menganggap bahwa kondisi terumbu karang masih baik-baik saja. Partisipan menganggap bahwa dengan adanya kegiatan pencegahan pengrusakan terumbu karang yang belakangan ini mulai intens dijalankan membuat kondisi terumbu karang sudah mulai membaik, walaupun belum sepenuhnya normal seperti dulu. Cesar dan Chong (2000) mengemukakan:

"Mengapa ekonom ingin nilai sesuatu seberharga terumbu karang? Jawabannya bisa jadi, 'karena terumbu karang yang begitu indah, kami ingin memastikan bahwa anak cucu kita dapat menikmatinya juga.' Namun, ada banyak masyarakat pesisir yang tidak menyadari barang dan jasa yang disediakan ekosistem terumbu karang dan yang tidak menghargai hubungan kompleks dari dunia alam."

Mengingat besarnya manfaat dari terumbu karang ini bagi masyarakat setempat, maka butuh sikap nyata baik dar masyarakat sekitar maupun pemerintah setempat. 


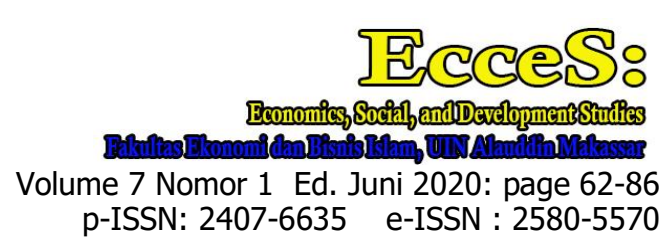

Pemerintah harus mulai mengeluarkan kebijakan nyata yang dapat membatasi kegiatan pengrusakan yang terjadi, memperbaiki pariwisata yang lebih berprinsip ekopariwisata, dan memanfaatkan potensi terumbu karang yang ada sebagai alternatif penambahan pendapatan daerah. Dalam hasil wawancara ditemukan bahwa partisipan berharap pemerintah terutama dari Dinas Perikanan dan Kelautan Kabupaten Mamuju mau ikut bekerja melestarikan terumbu karang di pulau ini. Mulai dari perealisasian program pengembangbiakkan atau rehabilitasi terumbu karang, hingga tidak melindungi pelaku pengebomman ikan. Dengan adanya payung hukum, maka setiap yang melanggar akan diberikan sanksi/hukuman, dan diharapkan masyarakat dapat lebih menghargai ekosistem terumbu karang. Adanya payung hukum dan regulasi yang jelas tanpa merugikan masyarakat lokal dapat memberikan perlindungan lebih lanjut, patroli penegakan hukum harus ditingkatkan dengan seringnya melakukan patroli di daerah yang butuh pengawasan berlebih (Fox et al., 2001; Hakim, 2013). Dengan demikian aspek kelembagaan perlu diperkuat. Kerja sama antara perangkat desa dan Dinas Kelautan dan Perikanan Kabupaten Mamuju dibutuhkan, terutama dalam hal pemberdayaan masyarakat agar lebih kreatif dalam pemanfaatan hasil laut, serta modernisasi dan inovasi teknologi baik itu alat tangkap, tambak, dan produksi hasil laut. Selain itu, dari sektor pariwisata diharapkan Dinas Pariwisata dan Kebudayaan Kabupaten Mamuju mampu menambah sarana dan prasarana wisata, sehingga dapat menarik wisatawan lebih banyak lagi, serta minimalisir potensi limbah. Sebagai penerapan pembangunan berkelanjutan, sesuai dengan temuan Tegar dan Gurning (2018) bahwa konsep ekowisata juga dapat diterapkan untuk mendukung pengembangan pariwisata berkelanjutan

Perencanaan pengelolaan sumber daya terumbu karang diharapkan memberi dampak yang positif bagi terumbu karang yang ada disekitarnya. Hanya pembangunan yang direncanakan dan dikelola sesuai dengan prinsip pembangunan ekonomi yang menjamin kelestarian sumber daya alam terumbu karang sekaligus pemberdayaan masyarakat. Pembangunan yang bertujuan untuk meningkatkan pendapatan masyarakat dapat diselaraskan proses pembangunannya dengan kelestarian sumber daya alam pesisir, yaitu dengan cara memegang teguh dimensi pembangunan yang berkelanjutan (Sialagan, 2010). Konsep blue economy relevan untuk diterapkan pada sektor perikanan melalui pengembangan bisnis yang inovatif dan kreatif berdasar prinsip efisiensi di alam, tanpa adanya limbah yang terbuang, memunculkan kesempatan wirausaha serta menciptakan lapangan kerja, dengan kreativitas dan inovasi, dengan strategi pembangunan perikanan 
Lisa Nursita. Menggagas Pembangunan Blue Economy ...

dan kelautan yang terstruktur dan sistematis akan menciptakan sinergi antara stakeholder (Pauli, 2010; Hakim, 2013). Penerapan konsep ini mampu memunculkan kreativitas dan inovasi dalam pengelolaan terumbu karang di Pulau Karampuang tanpa merusak lingkungan, dan sebaliknya dapat menghasilkan suatu manfaat ekonomi.

Diversifikasi mata pencaharian penduduk sekitar juga diperlukan untuk mengurangi tekanan dalam penggunaan terumbu karang. Hal ini dapat dilakukan dengan meningkatkan skill/kemampuan masyarakat sekitar dengan alternatif kerjaan lain yang dapat memberikan pendapatan bagi mereka, serta meningkatkan pengetahuan orangtua tentang pentingnya pendidikan pada anak mereka. Penyuluhan terhadap peran dan manfaat terumbu karang bagi kehidupan perlu dilakukan lebih intensif agar masyarakat dapat lebih menghargai keberadaan terumbu karang.

\section{KESIMPULAN / CONCLUSION}

Untuk mendorong pembangunan blue economy terumbu karang di perairan Pulau Karampuang, perlu dipertahankan keberadaannya, karena bersifat investasi untuk manfaat yang lebih besar di masa mendatang. Terumbu karang di kawasan perairan Pulau Karampuang oleh masyarakat lokal dimanfaatkan baik dari segi sosial ekonomi, yakni sebagai tempat mencari nafkah utama bagi masyarakat sekitar, sebagai tempat wisata, penahan gelombang, dan bahan bangunan. Terumbu karang juga menjadi penyumbang pendapatan daerah bagi Kabupaten Mamuju. Kegiatan-kegiatan yang merusak terumbu karang di perairan Pulau Karampuang adalah pengeboman, penambangan karang, penembakan ikan, dan aktivitas pariwisata yang tidak berkelanjutan. Langkah-langkah pelestarian terumbu karang di Pulau Karampuang hanya berupa himbauan dan sosialisasi oleh perangkat desa, orang tua yang dihormati, Dinas Pariwisata dan Kebudayaan Kabupaten Mamuju, dan Dinas Perikanan dan Kelautan Kabupaten Mamuju. Untuk itu perlu pengawasan dan kerja sama antara masyarakat dan pemerintah untuk melestarikan terumbu karang agar bisa dimanfaatkan untuk pemenuhan kebutuhan dan peningkatan kesejahteraan masyarakat terutama nelayan.

Implikasi dari adanya penelitian ini adalah dengan mengetahui besarnya manfaat sosial ekonomi terumbu karang berbasis pembangunan blue economy bagi masyarakat Desa Karampuang, dan bagaimana perlakuan penduduk terhadap terumbu karang, maka dapat diberikan beberapa saran kebijakan yang dapat dilakukan pemerintah setempat. Pentingnya ketersediaan payung hukum yang jelas bagi masyarakat setempat yang melakukan penambangan karang baik itu yang mati maupun yang hidup. Dengan adanya payung 
hukum, maka setiap yang melanggar akan diberikan sanksi/hukuman, dan diharapkan masyarakat dapat lebih menghargai ekosistem terumbu karang. Selain dari memperkuat aspek kelembagaan, juga dibutuhkan inovasi teknologi baik modernisasi alat tangkap ikan dan tambak, serta peningkatan kreatifitas masyarakat melalui pemberdayaan dalam pemanfaatan hasil laut yang dihasilkan oleh terumbu karang Pulau Karampuang, terakhir meminimalkan/memanfaatkan limbah yang dihasilkan sektor pariwisata dengan penerapan ekowisata. Dengan demikian, konsep perencanaan pengelolaan terumbu karang berprinsip berkelanjutan atau blue economy yang mengintegrasikan antara aspek kelembagaan, aspek ekonomi dan keberlanjutan lingkungan perlu dilakukan dengan segera. Diversifikasi pekerjaan juga perlu dilakukan, agar tekanan terhadap terumbu karang berkurang. Terakhir, penyuluhan terhadap peran dan manfaat terumbu karang bagi kehidupan perlu dilakukan lebih intensif agar masyarakat dapat lebih menghargai keberadaan terumbu karang.

\section{DAFTAR PUSTAKA / REFERENCES}

Adrianto, L. 2006. Pengantar Penilaian Ekonomi Sumber Daya Pesisir dan Laut. Dept. Manajemen Sumberdaya Perairan. Fakultas Perikanan dan Ilmu Kelautan. Pusat Kajian Sumberdaya Pesisir dan Lautan-IPB.

Ahmed, M., Chong, C. K. dan Cesar, H. 2005. Economic Valuation and Policy Priorities for Sustainable Management of Coral Reefs. Revision (Ed). Pinang, Malaysia: World Fish Center.

Bengen, D. G., Eidman, M. dan Boer, M. 2001. Kontribusi Ekosistem Mangrove Terhadap Struktur Komunitas Ikan di Pantai Utara Kabupaten Subang, Jawa Barat. Jurnal Pesisr dan Lautan.

Burke, L., Selig, E. dan Spalding, M. 2002. Terumbu karang yang terancam di Asia Tenggara (ringkasan untuk Indonesia), World Resources Institute, Amerika Serikat: World Resources Institute.

Cesar, H. dan Chong, C. K. 2000. Economic Valuation and Policy Priorities for sustainable Management of coral Reefs Economic Valuation and Socioeconomics of Coral Reefs: Methodological Issues and Three Case Studies. Economic Valuation and Policy Priorities for Sustainable Management of Coral Reefs,(1721), pp. 14-40. 
Lisa Nursita. Menggagas Pembangunan Blue Economy ...

Cesar, H. S. J. 2000. Coral Reefs: Their Functions, Threats and Economic Value, in Cesar, H. S. . (ed.) Collected Essay on the Economics of Coral Reefs. CordioDepartemen Biology and Environmental Science. Sweden: CORDIO, Department for Biology and Environmental Sciences, Kalmar University, p. 14.

Cinner, J. E. et al. 2013. 'Evaluating Social and Ecological Vulnerability of Coral Reef Fisheries to Climate Change', Journal List PLoS One, 8(9). Available at: https://www.ncbi.nlm.nih.gov/pmc/articles/PMC3770588/\#.

Dutton, I. m. et al. 2001. Sikap dan Persepsi Masyarakat Mengenai Sumberdaya Pesisir dan Laut di Indonesia. Jurnal Pesisir dan Lautan Indonesian Journal Coastal and Marine Resources. 3(3). pp. 46-52.

Fauzi, A. 2006. Ekonomi Sumber Daya Alam dan Lingkungan. Jakarta: PT. Gramedia Pustaka Utama.

Fox, H. et al. 2001. Increased Coral Cover in Komodo National Park, Indonesia: Monitoring for Management Relevance. Jurnal Pesisir dan Lautan Indonesian Journal Coastal and Marine Resources. 3(3), pp. 27-36.

Hakim, M. F. 2013. Blue Economy Daerah Pesisir Berbasis Kelautan dan Perikanan. Economics Development Analysis Journal, 2(2).

Ikawati, Y. et al. 2001. Terumbu karang di Indonesia. Masyarakat Penulis IImu Pengetahuan dan Teknologi (MAPPIPTEK).

Karubaba, C. T., Bengen, D. G. dan Nikijuluw, V. P. H. 2001. Kajian Pemenuhan Kebutuhan Pangan Nelayan oada Musim Timur dan Musim Barat Kaitannya dengan Pemanfaatan Sumber Daya Pesisir. Jurnal Pesisir dan Lautan Indonesian Journal Coastal and Marine Resources. 3(3), pp. 1-13.

Kordi, K. M. G. 2010. Ekosistem Terumbu Karang. Jakarta: Penerbit Rineka Cipta.

Mira, M., Firdaus, M. dan Reswati, E. 2014. Penerapan Prinsip Blue Economy pada Masyarakat Pesisir di Kabupaten Brebes, Jawa Tengah. Buletin Ilmiah Marina Sosial Ekonomi Kelautan dan Perikanan, 9(1), p. 17.

Mira, M., Saptanto, S. dan Hikmah, H. 2017. Valuasi Nilai Ekonomi Terumbu Karang Di Banda Neira, Jurnal Sosial Ekonomi Kelautan dan Perikanan, 12(1), p. 11.

Moleong, L. J. 1995. Metode Penelitian Kualitatif. Bandung: PT. Remaja Rosdakarya.

Nessa, N., Jompa, Jamaluddin, dan Hasmin. 2014. Ekosistem Terumbu Karang Valuasi Ekonomi. Makassar: USAID, UNHAS, Pustaka Al-Zikra.

Pauli, G. 2010. The Blue Economy. Meksiko: Paradigm Publications. 
Ramadhan, A., Lindawati, L. dan Kurniasari, N. 2016. Nilai Ekonomi Ekosistem Terumbu Karang Di Kabupaten Wakatobi. Jurnal Sosial Ekonomi Kelautan dan Perikanan. 11(2), pp. 133-146.

Saefuddin, A. 2014. Perguruan Tinggi, Peran Pemerintah Dan Pengembangan Blue Economy. Risalah Kebijakan Pertanian dan Lingkungan: Rumusan Kajian Strategis Bidang Pertanian dan Lingkungan. 1(3), pp. 135-142.

Seenprachawong, U. 2001. An Economic Analysis of Coral Reefs in the Andaman Sea of Thailand. Research. Reports. Economy and Environment Program for Southeast Asia (EEPSEA).

Sembiring, I., Wantasen, A. S. dan Ngangi, E. LA. 2012. Kajian Sosial Ekonomi Masyarakat di Desa Tumbak Kabupaten Minahasa Tenggara. Jurnal Ilmiah Platax, I(1), pp.29-36.

Sialagan, W. M. 2010. Perilaku Sosial Ekonomi Masyarakat dalam Mengelola Terumbu Karang. Jurnal IImiah Manajemen Bisnis. 10(3), pp. 183-188.

Smith-Godfrey, S. 2016. Defining the Blue Economy. Maritime Affairs: Journal of the National Maritime Foundation of India, 12(1), pp. 58-64.

Sudirman et al. 2006. Kondisi dan Potensi Sumberdaya Terumbu Karang di Kabupaten Bulukumba. Laporan Penelitian Balitbangda. Sulawesi Selatan.

Sukarniati, L. and Khoirudin, R. 2017. 'Analisis Kelembagaan Penerapan Konsep Blue Economy Pada Tambak Udang (Studi Kasus Di Dusun Ngentak Desa Poncosari Kecamatan Srandakan Kabupaten Bantul)', Jurnal Ekonomi Pembangunan STIE Muhammadiyah Palopo, 3(2), pp. 52-65.

Suparmoko, M. 2014. Ekonomi Sumber Daya Alam dan Lingkungan Suatu Pendekatan Teoritis. 4 Revisi. Yogyakarta: BPFE.

Tegar, D. dan Saut Gurning, R. O. 2018. Development of Marine and Coastal Tourism Based on Blue Economy. International Journal of Marine Engineering Innovation and Research, 2(2).

Tripon, A. 2014. Innovative Technology for Sustainable Development of Human Resource Using Non Formal and Informal Education. Procedia Technology, XII, pp. 598-603.

World Wide Fund For Nature (WWF) Baltic Ecoregion Programme. 2015. Principles for a Sustainable Blue Economy The Purpose of the Principles, World Wide Fund For Nature (WWF). 